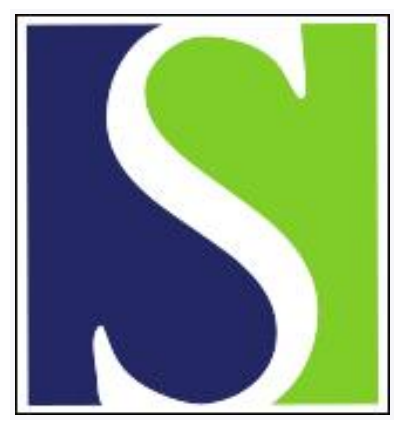

Scand J Work Environ Health 2011;37(3):173-185

https://doi.org/10.5271/sjweh.3146

Published online: 03 Feb 2011, Issue date: May 2011

Shift and night work and long working hours - a systematic review of safety implications

by Wagstaff AS, Sigstad Lie J-A

Affiliation: Aviaton Medicine, 0313 Oslo, Norway. a.s.wagstaff@flymed.uio.no

Refers to the following texts of the Journal: $1998 ; 24$ suppl 3:43-48 2005;31(5):329-335 2006;32(3):232-240

The following articles refer to this text: $2011 ; 37(3): 169-171$;

2012;38(6):560-567; 2012;38(4):291-297; 2013;39(4):361-368;

2014;40(2):146-155; 2014;40(6):621-630; 2015;41(3):268-279;

2015;41(4):368-376; 2017;43(6):578-586; 2018;44(4):394-402;

2018;44(4):385-393; 2020;46(4):446-453; 2020;46(5):480-487;

2020;46(5):508-515; 2021;47(6):415-424

Key terms: accident; long working hours; night work; safety; shift work; systematic review

This article in PubMed: www.ncbi.nlm.nih.gov/pubmed/21290083

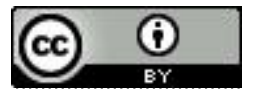




\title{
Shift and night work and long working hours - a systematic review of safety implications
}

\author{
by Anthony Sverre Wagstaff, MD, DAvMed, PhD, MBA, ${ }^{1,2}$ Jenny-Anne Sigstad Lie, PhD ${ }^{1}$
}

\begin{abstract}
Wagstaff AS, Sigstad Lie J-A. Shift and night work and long working hours - a systematic review of safety implications. Scand J Work Environ Health. 2011;37(3):173-185. doi:10.5271/sjweh.3146

Objective In order to devise effective preventive strategies, it is important to study workplace stressors that might increase the risk of workplace accidents - both affecting workers themselves as well as causing harm to third-parties. The aim of this report is to provide a systematic, updated overview and scientific review of empirical research regarding accidents in relation to long work hours and shift work, primarily based on epidemiological studies.

Methods The search for articles was part of a large review study on the effects of work hours on various health outcomes, safety, and performance. The search strategy included 5 international scientific databases, and nearly 7000 articles were initially identified using our search string. Following the application of inclusion and exclusion criteria, 443 publications were found and evaluated using a pre-defined scoring system. Of these, 43 concerned safety and accidents but only 14 were considered to be of high quality (total score 2 or 3 on a scale from 0-3) and therefore used for this study.
\end{abstract}

Results Both shift work and long working hours present a substantial and well-documented detrimental effect on safety - all the studies that are included in this review have one or more significant findings in this respect. The trends are quite coherent although the increases in accident rates are mostly from $50 \%$ to $100 \%$. In epidemiological terms, these may be considered rather small differences. The use of such data is therefore only of importance if the accident incidence is high or if accidents may have large effects.

Conclusions The findings are most relevant to safety-critical activities such as the transport and health sectors. Work periods $>8$ hours carry an increased risk of accidents that cumulates, so that the increased risk of accidents at around 12 hours is twice the risk at 8 hours. Shift work including nights carries a substantial increased risk of accidents, whereas "pure" night work may bring some protection against this effect due to resynchronization. The evaluated studies give no clear indications of any age or gender being specifically susceptible to or protected against the effects of work times scheduling on accident risk.

Key terms accident; shift work.

Occupational injury accounts for about $15 \%$ of occupation-related deaths worldwide, or about 350000 per year, not including commuting deaths (1). The connection between work exposure and injury is usually clear, in contrast to many occupational diseases where the cumulative effects of occupation may coexist and interact with many other causative factors. The secondary effects of workplace accidents to third-parties (eg, transport passengers, hospital patients, or the general public) increase the importance of preventing occupational accidents. Most occupational accidents are preventable. In order to devise effective preventive strategies, it is of interest to study workplace stressors that might increase the risk of workplace accidents, both affecting workers themselves as well as causing harm to third-parties.

The counting of accidents in an occupational setting is relevant as one measure of occupational safety. Most accidents or adverse events are due to human rather than technical failures. This is a well-known fact, for example in the transport sector. Also in healthcare this is becoming a well-established fact, and it is probably the case for all complex and potentially hazardous systems where humans interact (2). Since we know that fatigue, sleep loss, and circadian desynchronization have detrimental effects on human performance and decision-making (3), the potential effects of work hours

1 National Institute of Occupational Health, Oslo, Norway.

2 Institute of Aviaton Medicine, Blindern, Norway. 
on safety at work should be self-evident. Although there have been some review studies in recent years concerning the magnitude of such effects $(4,5)$, very few, if any, have been systematic in their selection of studies. With "non-standard" working hours becoming an increasingly prominent aspect of modern society, it becomes even more important to understand the costs of this trend in order to make well-founded policy. In Norway, for example, the number of employees who are involved in shift systems has increased gradually throughout this decade and was $23.4 \%$ in 2008 , according to Statistics Norway (the Norwegian National Bureau of Statistics).

This study is therefore an attempt to provide a balanced review of the current knowledge in this field. In order to achieve such a balanced review, a systematic approach was chosen. Such an approach provides less researcher bias than a narrative review. Although some good quality research papers may be missed, the balance needed for correct conclusions is more readily attainable in the systematic review. The aim of this report is to give an updated overview and scientific review of empirical research regarding accidents in relation to long work hours and shift work, primarily based on epidemiological studies.

\section{Methods}

A major concern when planning the present study was to obtain a representative sample of published papers in this field.

\section{Search strategy}

The search for articles was part of a large review study on the effects of work hours on various health outcomes, safety, and performance (6). The search aimed to identify relevant articles published in peer-reviewed psychological and medical journals written in English. The rationale for this choice is the assumption that most of the important findings will be reported in English regardless of the country of origin.

In cooperation with the librarians at the National Institute of Occupational Health (NIOH), online searches were conducted in the PubMed, Embase, ISI, OSH_ROM, and Psychinfo databases, for all years up to June 2008. Only search terms for exposure were used. The search was based on article titles, and the search terms were the following: "overtime"," long work* hours", "extended hours", "shift work", "extended work* period*", "extended work* shifts"," work* time"," work* hours", "work* schedule*", "shift duration*", "compressed work* week", "reduced work* time", "short* work* day", "part-time work", "night work"," weekend work", "irregular work", "rotating night shift*", "12-hour shift", "12 hour day", "hour at work", "time of day", "8-hour shift", "time of day", "long workhours", "hours of work", "shiftwork difficulties", "shift systems", "night shift", "three shift", "two shift".

The above search string was the final string we used. Before this, we performed several trial strings where comparison was performed with earlier research studies in the field to see that we were getting a large number of relevant "hits".

Searches were done first on titles, abstracts, and keywords. The search strategy was gradually narrowed until we only covered titles. This narrowing was necessary in order to achieve manageable numbers. The resulting 6889 references (for all outcomes) were then considered just about practically manageable.

\section{Selection criteria}

Inconsistencies between the five literature databases regarding import of references resulted in a number of duplicates/triplets etc that were excluded. This had to be done largely manually, due to the same articles being slightly differently entered into the different databases. References to papers with unknown author or publication year were also excluded, as well as papers concerning subjects other than human health, safety, or performance. Papers on circadian variation of physiological processes in general, social effects of shift work, and papers dealing with exposures outside the worksite were also excluded.

\section{Inclusion criteria}

For the remaining references, the abstracts were examined with regard to a set of inclusion criteria. For an article to be included in the review, it should: (i) have an explicit measure of the exposure (eg, shift work, night work, extended work shift, etc.); (ii) have an explicit measure of the outcome (eg, car accidents, near-miss incidents, work-related injuries, work injury, fatiguerelated error, serious medical errors, changes in mortality in hospitalized patients etc.); and (iii) explicitly test the association between the exposure and the outcome measure.

The included studies were mostly cohort studies, case-control studies, or cross sectional studies. In addition, review articles were included for the discussion part. This review includes articles evaluating associations between different work hours and safety or accidents.

The search and selection process is visualized in figure 1 on the following page. 


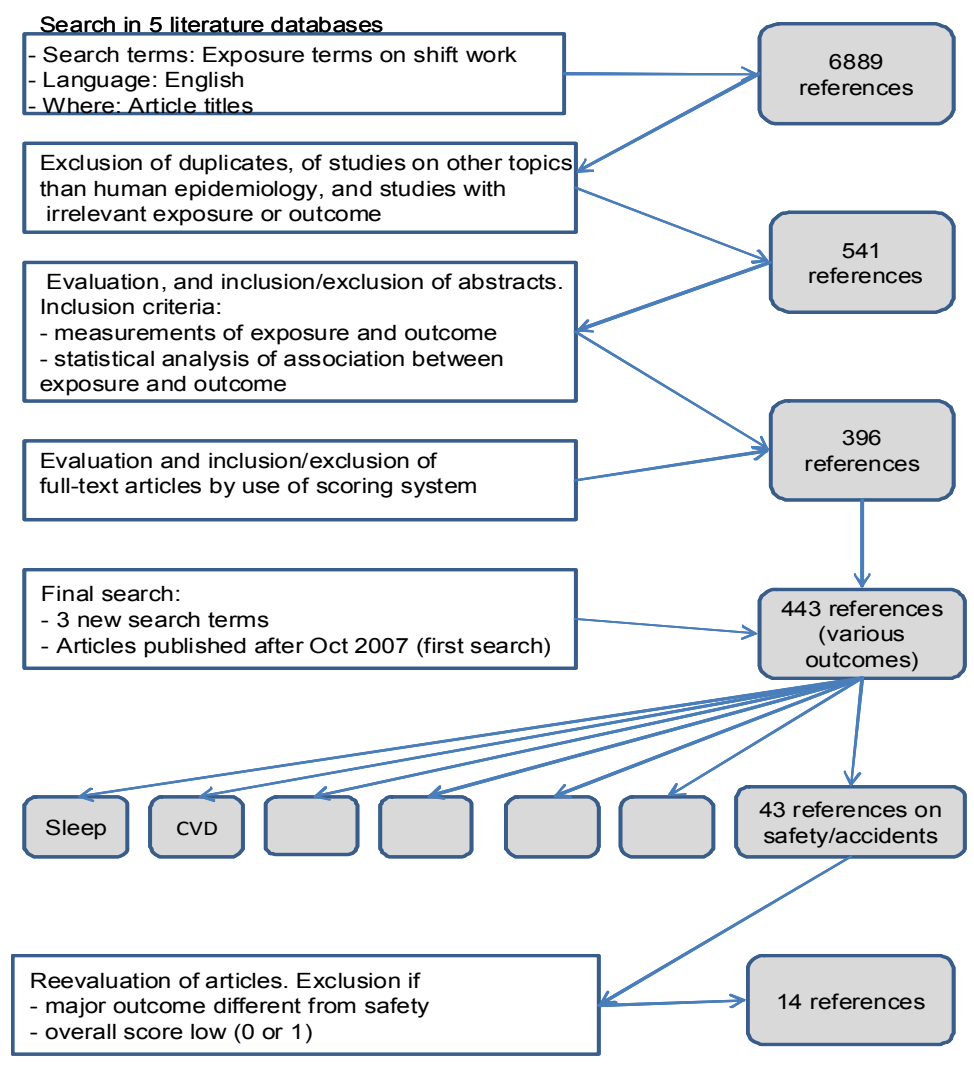

Figure 1. The search and selection process.

\section{Evaluation of publications}

The included papers (fulltexts) were evaluated for content and quality by $\mathrm{NIOH}$ scientists using a scoring system specially developed by the Department of Occupational Medicine and Epidemiology (table 1). Only articles with an overall score of 2 or 3 are included in the present review.

\section{Description of the individual studies}

Smith \& Colligan (7) performed a cross-sectional study addressing health and safety consequences of shift work among food processing workers from 8 American plants. Worksites which represented companies volunteering to participate were included. Participants were randomly selected from each worksite, and included employees who had been on their current shift for $\geq 6$ months. A questionnaire was mailed to all participants, including questions on health problems per year, presence or absence of disease, and patterns of eating, sleep, alcohol, and tobacco consumption. Completed questionnaires were returned from 885 food processing workers (response rate $60 \%$ ). In addition, an evaluation of company records was performed in order to characterize the consequences of day versus night shifts on occupational health and safety. The mean age for day workers, afternoon shift workers, night shift workers, and rotators was 42 years, 36 years, and 38 years, respectively. The results also indicated poorer sleep, greater risk of sickness absence, and a higher alcohol consumption among shift workers compared to the day workers.

Subanalyses for just the rotating shift workers showed that $44 \%$ of these workers needed $\geq 1$ week to adjust their sleep pattern. Night work was the most disruptive shift in terms of sleep problems. A significant higher frequency of work injury was found among male rotators than day workers. The actual injuries included sprains, superficial injuries and open wounds, contusions, and fractions. (Due to their low number, female rotating shift workers were excluded from these analyses). The authors concluded that rotating shift work is the most detrimental work system for this study population.

The strengths of this study include the use of two different sources for outcome information, and a quite large study size. Limitations include the non-representative sample of worksites (only volunteering companies supplied subjects), a moderate response rate, and a lack of information on some aspects of the methodology. 
Table 1. Variables extracted from each of the selected articles and tabulated if present.

\begin{tabular}{|c|c|}
\hline Age & Mean or age span \\
\hline Gender & $\begin{array}{l}\text { M(ale), } \mathrm{F}(\text { emale), } \\
\text { MF (if both sexes and }>50 \% \text { men) } \\
\text { FM (if both sexes and }>50 \% \text { women) }\end{array}$ \\
\hline Exposure & $\begin{array}{l}\text { N: shift work or night shift work } \\
\text { S: Specific shift systems } \\
\text { DL: Overtime or extended work hours } \\
\text { DS: Part time or short work hours }\end{array}$ \\
\hline Primary outcome & $\begin{array}{l}\text { Safe or safety in combination with other outcomes. (The original search included all different health out- } \\
\text { comes, such as safety and performance and mortality among patients) }\end{array}$ \\
\hline Design & $\begin{array}{l}\text { CC: Case-control study } \\
\text { CS: Cross-sectional study } \\
\text { RS: Registry-based study } \\
\text { CT: Clinical trials } \\
\text { FT: Field trials } \\
\text { PC: Prospective cohort studies } \\
\text { RC: Retrospective cohort study }\end{array}$ \\
\hline Response rate & Proportion of invited subjects who actually participated \\
\hline Selection bias & $\begin{array}{l}\text { Yes: if not representative sample, due to the sampling method } \\
\text { Possible: if sample may possibly not represent the population } \\
\text { No: if representative sample }\end{array}$ \\
\hline Information bias & $\begin{array}{l}\text { 2: No misclassification of exposure or outcome } \\
\text { 1: Non-differential misclassification of exposure or outcome } \\
\text { 0: Differential misclassification of exposure or outcome }\end{array}$ \\
\hline Residual confounding & $\begin{array}{l}\text { Yes: if potential confounders have not been adjusted for } \\
\text { Possible: if some potential confounders may not have been adjusted for } \\
\text { No: if all potential confounders seem to have been adjusted for }\end{array}$ \\
\hline $\begin{array}{l}\text { Total validity } \\
\text { (Can the results of the article be } \\
\text { trusted?) }\end{array}$ & $\begin{array}{l}\text { 3: Yes, definitely } \\
\text { 2: Probably } \\
\text { 1: Doubtful } \\
0 \text { : No }\end{array}$ \\
\hline $\begin{array}{l}\text { Overall score } \\
\text { (The usefulness of the article in } \\
\text { evaluating the actual question) }\end{array}$ & $\begin{array}{l}\text { 3: Key article } \\
\text { 2: Valuable } \\
\text { 1: Of little value } \\
\text { 0: No real value }\end{array}$ \\
\hline
\end{tabular}

Gold et al (8) performed a cross-sectional study among female nurses in a Massachusetts hospital, in order to assess the impact of different work schedules on sleep, sleepiness and accident rates. In 1986, a total of 878 female registered nurses, licensed practical nurses, and other ancillary staff were invited to participate. The participants were asked to record their working shifts for four weeks. Information was also collected regarding a number of other factors, including sleep and wake times, alcohol consumption, medication, nodding off at work or while driving to and from work in the past year, and accidents and errors and "near-miss" accidents in the past year. Of the 878 women, 687 (78.3\%) returned the questionnaire, of whom 635 (72.4\%) were included (593 registered nurses and 42 female licensed practical nurses). The following shift categories were included: "day/ evening"; "night"; "rotator"; "day/evening, occasional night"; "night, occasional day/evening", and "part-time rotator". Odds ratios (OR) were calculated by logistic regression and other risk factors were included. The OR of reporting poor quality sleep among night workers and rotators were 1.81 [ $95 \%$ confidence interval $(95 \% \mathrm{CI})$ 1.02-3.22] and 2.82 (95\% CI 1.79-4.45) respectively, when compared to day/evening nurses. Nodding off on the night shift occurred at least once per week among $35.3 \%$ of rotators and $20.7 \%$ of day/evening nurses working occasional nights. When compared to day/evening workers, rotators had an OR of $3.92(95 \%$ CI 2.45-6.30) and night nurses an OR of 3.62 (2.02-6.48) of nodding off while driving to and from work. OR of reporting any accident or error among rotators was 1.97 (95\% CI 1.07-3.63), and of near-miss accidents 2.47 (95\% CI 1.56-3.89), compared with day/evening nurses. For night workers, the OR of near miss automobile accidents was 1.92 (95\% CI 1.05-3.52). Age group, duration of work at the hospital, and use of alcohol to get to sleep were all adjusted for in the analyses. This study was strengthened by its use of a socioeconomic homogenous group, and adjustment for several relevant confounders.

The study was limited by self reporting of exposure and outcome, and an exposure assessment that covered only a short period.

Hänecke et al (9) used data from the Confederation of Workers' Compensation Board to investigate whether accident risk could be a function of hour at work and 
time of day in the German working population. Data on registered accidents for the year 1994 was obtained, and included more than 1.2 million accidents. All accidents were listed according to time of day and hour of work. Since data are not registered in Germany on number of hours per day, and what time of day people work, the authors constructed different exposure models that were checked for consistency with two previously conducted, independent German studies. For comparing the risk of having an accident according to hour at work and time of day, the authors calculated the relative accident risk as the ratio of the accident frequencies (in percent) to the calculated exposure data of the German working population (in percent). The percentages were based on the relevant distribution (ie, hour at work or time of day).

The results showed a high number of accidents for people starting their job at 06:00, 07:00 and 08:00. A small peak of work accidents was found among people starting work at 14:00 and an even lower peak among people starting their work at 22:00-24:00. Concerning duration of work, data supported an exponentially increasing accident risk beyond the $9^{\text {th }}$ hour of work. The authors found a statistically significant interaction between time of day and hour at work for absolute accident frequencies. The results suggest an exponential increase in accident risk beyond the $9^{\text {th }}$ hour of work, particularly when shift start times differ from those of normal workdays. However, time of day (ie, night or evening shifts) had no clear effect on accident risk.

Limitations of this study include lack of adequate data on exposure and potential confounders, and the inclusion of a variety of occupations with different accident risks. A further limitation is limited information on material and methods.

Gander et al (10) performed a nationwide cross-sectional study among 301 New Zealand anesthetists, in order to evaluate the association between hours of work and fatigue-related clinical errors. A questionnaire and a return envelope were included with a newsletter to 433 New Zealand anesthetists in July 1997, and November 1997 (non-responders). The questionnaire included questions on work hours (eg, average number of hours and nights worked per week, the longest continuous period administering anesthesia during the last six months), demographic variables, self defined limits for maintaining patient safety and personal well-being, and fatigue-related errors. The response rate was $70 \%$. Whereas for most trainees night work implied roistered shifts, for most specialists night work implied being on call. Five percent of specialists and $16 \%$ of trainees reported an average working week of $\geq 70$ hours. Fortyseven percent of specialists and $79 \%$ of trainees reported that the longest working week during the previous six months was $\geq 70$ hours. Fifty percent of trainees and
$27 \%$ of specialists reported an average working week that exceeded their own limits for maintaining patient safety. Eighty-six percent of the respondents reported fatigue-related errors. Among the 14\% who reported never making a fatigue-related error in clinical management, mean age and mean years of experience were significantly higher than among those who reported errors (47.8 years versus 42.6 years and 21.4 years versus 14.4 years respectively). Logistic regression analyses were carried out to test whether the likelihood of reporting a fatigue-related error in the last six months was related to any aspect of work patterns. Associations were found for specialists $(\mathrm{N}=183)$, but not trainees $(\mathrm{N}=41)$, between number of nights of work-related sleep disturbance in the last fortnight and the likelihood of reporting an error (risk ratio 1.25, 95\% CI 1.06-1.49). Furthermore, significant associations were found between fatigue-related errors and having exceeded self-defined limits for safety.

The study had some limitations. All data on exposure and outcome were subjective. The types of errors to be recalled were not specified, and number of recalled errors was not stated. The results from multiple, logistic regression models were not properly tabulated.

Landrigan et al (11) conducted a prospective, randomized study in two intensive care units at a Boston hospital, in order to compare the rates of serious medical errors made by interns who worked according to either a traditional or an intervention schedule. One of the hospital units was a medical intensive care unit and the other a coronary care unit. The traditional schedule included extended work shifts ( $\geq 24$ hours) every other shift. In the intervention schedule, extended work shifts were eliminated and maximum number of work hours per week was reduced to 63 . The study was conducted from July 2002 to June 2003, involving 634 admissions during a total of 2203 patientdays. Interns were randomly assigned to work either the traditional schedule ( 3 interns and 3 third-year residents) or the intervention schedule ( 3 interns and two secondyear residents) in each of the two departments. All interns rotated through both schedules. Incidents were identified continuously by a multidisciplinary team. Rating of incidents was performed independently by two physicians who were unaware of the interns' identity and schedule assignment. The authors compared the respective rates of intern-associated medical errors per patient-day, and the rates of type-specific errors per patient-day. Interns made $35.9 \%(\mathrm{P}<0.001)$ more serious medical errors, and $20.8 \%(\mathrm{P}=0.03)$ more serious medication errors during the traditional schedule than during the intervention schedule. The total rate of serious errors was $22.0 \%(\mathrm{P}<0.001)$ higher during the traditional schedule than during the intervention schedule.

The strengths of this study include the prospective, randomized design (crossover eliminating confounding), 
a socioeconomic homogenous group, and a high agreement (kappa) between the two physicians rating incidents and adverse events. The study's limitations include a possible bias caused by the inability to blind the medical observers to the schedule of the interns. Another limitation is the involvement of work hours long enough to induce attentional failures also in the intervention schedule. Staffing limitations and restricting observations to only one intern at a time may have resulted in underreporting of serious errors during daytime hours, when two or more interns were working in different parts of the unit.

Rogers et al (12) performed a cross-sectional study among 393 American hospital staff nurses to examine the work patterns and evaluate if there is a relationship between hours worked and patient safety. Initially, a random sample of 4320 members of the American Nurses Association was invited during the winter of 2002. Of the 1725 who returned the questionnaire, 891 eligible nurses (full-time workers) received instructions and two logbooks, covering a two-week period each. Of this group, 362 nurses returned both logbooks, and 31 returned only one logbook (response rate $\sim 40 \%$ ). All participants worked full-time as hospital staff nurses. The logbooks were used to collect information on 17-40 items per day including hours worked, overtime, days off, sleep/wake patterns, errors and near errors, as well as data on potential confounders, such as mood and caffeine intake. Data were collected on 5317 shifts. Scheduled shifts may be 8-, 12-, or even 16-hours long. Cut-points for classifying shift durations were chosen as 8.5 hours and 12.5 hours, to allow for a half-hour handover period of the shift.

On average, the participants worked 55 minutes longer than scheduled each day, with a significant higher proportion of overtime in shifts of shorter duration (8 hours). A work shift was classified as an overtime shift if the actual work hours were longer than the scheduled hours, or if the shift was reported as "scheduled overtime". A binary response for making an error during a worked shift was used as the primary outcome in analyses. Categorizations of errors and near errors were made by the study investigators. During the data-gathering period, 199 errors and 213 near errors were reported. Fifty-eight percent of the errors and $56 \%$ of near errors involved medical administration, $18 \%$ of the errors included procedural errors. Six percent of the errors and $29 \%$ of the near errors could not be categorized due to insufficient information. Logistic regression models were used to evaluate the associations between the risk of making an error/near error and the actual duration of the shift or overtime. Variables adjusted for included age, hospital size, and type of hospital unit. The OR of making an error increased with longer work hours. When compared with work hours up to 8.5 hours, the increased relative risks for work duration of $8.5-12.5$ hours and $>12.5$ hours were $1.85(\mathrm{P}=0.06)$ and $3.29(\mathrm{P}=0.001)$ respectively. Working overtime also increased the relative risk of making at least one error or near error. The OR for making an error when working $>40$ or 50 hours per week were $1.96(\mathrm{P}<0.0001)$ and $1.92(\mathrm{P}=0.0001)$, respectively.

The study's limitations include its low participation rate $(\sim 40 \%)$, a lack of analyses of drop-outs, the selfreporting of outcome, and a high proportion of nonclassified near errors.

Garbarino et al (13) performed a two-step study (retrospective and prospective) among Italian shift-working police drivers to evaluate the influence of sleep behavior on car accidents and the effect of prophylactic naps. The retrospective study included all 1195 highway vehicle accidents that occurred during the years 1993-1997 among 1195 police-drivers. In order to validate the results from the retrospective analyses, a prospective study was performed including 84 accidents, which occurred during 2003, involving 84 police drivers. All subjects were working on a fast-rotating, counter-clockwise roster, organized according to the following schedule: evening (19:00-01:00), afternoon (13:00-19:00), morning (07:00-13:00), and night (01:00-07:00). Sixty hours of rest followed each cycle. Data on accidents came from the Italian state traffic police official database. Accidents were classified according to whether the police officer was culpable or the victim. The Highway Company provided information road and traffic conditions. In the retrospective study, data on timing of the night sleep and naps preceding each shift was estimated based on information from phone interviews with all 1195 drivers collected during the year 1999.

In the prospective study, information on night sleep and timing of naps were collected in phone interviews within one week of the accident. The authors searched to include two processes in the analyses of night work and accidents: (i) circadian sleep propensity (process C) as a function of hour of accident, and (ii) sleep pressure due to prolonged wakefulness (process S). No statistical difference was found between the two datasets concerning sleep onset and duration.

In the retrospective study, a Cox regression analysis was used to assess the influence of factors related to the driver, context conditions (eg, weather, traffic, culpability), the time from start of the shift, and the processes $\mathrm{C}$ and $\mathrm{S}$ levels on accident risk. The results showed that night-time accident risk was mainly influenced by process S levels.

For both the prospective and the retrospective dataset, the authors used a mathematical model linking hourly number of accidents to process $\mathrm{S}$. No significant difference was detected between the two datasets. The 
effect of naps was evaluated by dividing subjects who had an accident during the evening/night shift into nappers and non-nappers. Based on a theoretical sleep variable, the number of accidents observed was compared with the expected number (in the absence of naps). For both datasets, a decrease of accidents was estimated among drivers having a prophylactic nap [38\% (standard deviation [SD] 8\%) in the retrospective group and 48\% (SD 19\%) in the prospective group], confirming that napping before working night shift is as an effective measure to prevent accidents. The strengths of this study were its design, which included both a prospective and a retrospective approach, the study of a socioeconomic homogenous group, and also the independent information on work hours and car accidents. A limitation was the lack of a control group of shift-working drivers, recruited independently of the occurrence of accidents.

Barger (14) performed a prospective, nationwide cohort study among interns in their first postgraduate year (2002-2003) in order to evaluate the association between work hours and shifts of extended duration $(>4$ hours), and incidents of involuntary sleeping and the risk of motor vehicle crashes. Graduates of US medical schools were invited to participate. Of a total of 3429 who volunteered to participate, 2737 (80\%) completed the baseline survey. Sixty-nine percent of the study participants commuted by car, and the average distance was 91.6 (SD 96.2) miles. Through monthly surveys including 60 questions, participants provided detailed information about work hours, documented vehicle crashes and near-miss incidents. An average of 1548 (SD 376) surveys were completed each month. The mean reported work hours for interns in the hospital was 70.7 (SD 26) hours per week, and mean monthly number of extended work shifts was 3.9 (SD 3.4).Validation of work hours by use of daily work diaries completed by a subgroup of 192 participants, compared with direct observation of work hours showed a high correlation both for work hours and shifts of extended duration.

A total of 320 motor vehicle crashes were reported, with documentation obtained for 82 percent. MantelHaenszel OR for motor vehicle crashes incidents and near-miss incidents when commuting after an extended work shift was 2.3 (95\% CI 1.6-3.3), compared with commuting after a non-extended shift. For near-miss incidents, the corresponding OR was 5.9 (95\% CI 5.4-6.3). The authors also prospectively assessed the potential association between the monthly number of scheduled extended shifts and subsequent occurrence of motor vehicle crashes. Every extended shift that was scheduled per month increased the monthly rate of any motor vehicle crash by $9.1 \%$ (95\% CI 3.4-14.7), and $16.2 \%$ (95\% CI 7.8-24.7) for a motor vehicle crash during the commute from work. In months with $\geq 5$ extended shifts, the relative risk of falling asleep while driving or while stopped in traffic was significantly increased [OR 2.39 (95\% CI 2.31-2.44) and 3.69 (95\% CI 3.60-3.77)].

The strengths of this study include the use of a socioeconomic homogenous cohort, a high participation rate and a high validity of work hours. Use of in-person case-crossover design eliminated the need to adjust for potential confounders. Limitations include a potential for selection bias and recall bias.

Dong et al (15) used the national longitudinal survey of youth 1979 cohort (NLSY79) in order to measure the risk of work-related injuries in different industrial worker groups in the US. This sample is termed a "national sample" and consists of 12686 men and women who were subjected to a series of questions on work-related injuries and illnesses. These individuals were interviewed annually from 1979-1994 and biannually starting in 1996. The NLSY79 also collected information on work-hours, creating two summary variables for each year providing information on the total hours that a respondent worked. The NLSY respondents were also asked questions on occupational injuries since their last interview. For construction workers in particular, the data analysis focused on severe injuries, using the 1996 and 1998 surveys. Data were analyzed using a logistic regression model controlling for possible confounders. In construction, workers working $>8$ hours were found to have higher injury rates than those who worked 7 or 8 hours a day [OR 1.57 (95\% CI 1.56-1.58)]. For all production occupations ( $\mathrm{N}=4103)$, weekly hours $>50$ produced an OR for work-related injury of 1.98 (95\% CI 1.88-2.05). Shift work produced an OR of 1.21 (95\% CI 1.20-.21). The injury rate increased steadily along with the hours of overtime. The strengths of this study included its large size and non-selection-bias of the cohort and well-described statistical methods including control for possible confounders. A weakness is that both work-hours and injuries were self-reported. In addition, information on sample selection, response rate, and adjustment of variables was lacking.

Dembe et al (16) used the same cohort as mentioned above, but included all worker groups (including 10793 members of the cohort) in all 89729 person-years accumulated working time between 1987-2000. The primary outcome of interest in this study was the self-reported incidence of a work-related injury or illness. Four exposure categories were specified: (i) extended hours per week, (ii) extended hours per day, (iii) overtime, and (iv) extended commute time. A derived summary exposure variable, overtime or extended hour, was considered to be present if any of the four preceding variables were present. Regression models were devised, controlling for pos- 
sible confounding variables. Incident rates for reported work-related injuries and illnesses gradually increased with both hours per week and hours per day. Adjusted hazard ratio (HR) for extended hours per day $(\geq 12)$ was 1.37 (95\% CI 1.16-1.59). The strengths and weaknesses of the study were similar to the previous study, although this study had a longer time span and all occupations were included. However, occupational accidents or injuries were not reported exclusive of occupational illness.

Dembe et al (17) published a study on nonstandard shift schedules and the risk of job-related injuries. Again, NLSY was used, comprising data from 1987-2000, and analysed with multivariate regression. Cox proportional hazard regression techniques were used to derive HR comparing the relative risk of suffering a work-related injury among people working night, evening, rotating split, and irregular shifts - to the risks of those working conventional day shifts. Adjustments were made for age, gender, occupation, industry, and region. The calculated HR were 1.43 (95\% CI 1.26-1.62) for evening shifts, $1.36(95 \%$ CI $1.17-1.58)$ for rotating shifts, and 1.30 (95\% CI 1.12-1.52) for night shifts.

The strengths of the study includes a large sample and a longitudinal follow-up of this cohort along with well developed techniques for making the analysis as representative as possible. Limitations include self-reported information without external validation, which may increase susceptibility to recall error. In this study also, information on sample selection and response rate was lacking.

Hanowski et al (18) performed a field experiment study among 73 truck drivers working for one of three licensed trucking companies. Mean age of drivers was 31.9 years (range 24-58). Two questions were addressed: (i) overall sleep quantity (including all full days with $\leq 120$ minutes without actigraph) and (ii) sleep quantity prior to being involved in a critical incident (including all complete weeks of data). Unobtrusive data collection equipment was installed in the trucks, producing video tracking of both the drivers face and three views outside the truck. Critical incidents (crash, near-crash, or crash-relevant conflicts) were analyzed along with sleep recorded on an actigraph. Selection criteria for participation included drivers not wearing glasses and driving primarily at night. Driver participants were assigned to an instrumented truck to use on their normal delivery routes. The dataset was drawn from approximately 1.69 million miles of driving, but the start- and stop-points of the study were not clearly defined in the article. Paired t-tests were performed to compare drivers' mean sleep quantity with that before a critical incident. Fifty-eight critical incidents were reported in the $10^{\text {th }}$ and $11^{\text {th }}$ driving hours, and drivers received significantly less sleep in the period prior to a critical incident as compared to their mean overall sleep quality.
The study strength is primarily that both exposure and outcome data were objective, ie, in a "real-world" environment. Limitations of the study include its small sample size and possible selection bias since it is not clear how many of the drivers, who were selected or asked, decided not to participate.

Fransen et al (19) performed a cross-sectional analysis of the New Zealand blood donors health study among 15 $687(70 \%)$ participants who reported being in permanent employment. A self-administered questionnaire was used to collect information regarding occupation and work pattern, lifestyle behavior, sleep, and the occurrence of an injury at work requiring treatment from a doctor during the past 12 months. All variables were entered into a stepwise logistic regression analysis. Mutually adjusted relative risks (RR) of work injury were 1.89 (95\% CI 1.49-2.41) for rotating night shifts versus daytime work with no shifts and 1.75 (95\% CI 1.17-2.61) for working rotating shifts without night shifts. However for permanent night shifts, the RR was non-significant at $1.38(95 \%$ CI $0.93-2.00)$. For long work hours, the RR was 1.32 (95\% CI 1.12-1.55) for working $>40$ hours versus $\leq 40$ hours. This study has major strengths, spanning a wide range of ages and occupational groups in a large number of participants. Recall bias may be present to some extent due to selfreporting of both exposure and injury, and selection bias may be present in the $70 \%$ who chose to answer the questionnaire.

Vegso et al (20) performed a study among American workers in manufacturing in order to determine whether injury risk among manufacturing workers was related to hours worked during the previous week. As a part of ongoing analysis of health and safety at US locations of a large aluminum manufacturer, the investigators performed a case-crossover study of 1955 subjects, linking payroll data from a sample of plants with injury incidence data from a "real-time" incident management system. To exclude possible confounding by business cycles, a control-crossover design was employed, using uninjured co-workers employed on the date of the case injury. Paired t-tests were used to determine significance of the difference. Conditional logistic regression was used to assess dose-response. Hours worked prior to injury significantly exceeded hours during the control week. The HR for injury in the preceding week for $>64$ work hours in 7 days compared to those worked $\leq 40$ hours was 1.88 (95\% CI 1.16-3.05).

A strength of the study is that data were registrybased, avoiding subjective recall bias. A limitation of the study is that it included a relatively homogenous group of plants in a time period of economic-related strains. The degree to which extended work periods or overtime 
were due to choice or not was also difficult to distinguish in this dataset, thereby also a possible limitation on a wider application of the findings.

\section{General findings and discussion}

Shift work and work hour exposure data are often poorly reported. Important aspects of the exposure are often missed, such as timing of shifts, speed of rotation etc. Thus, many of the papers initially included for our study were found lacking in this respect. Long work hours and also shift work are work stressors that vary greatly both in quality and quantity. Such variations may or may not be easy to assess as local norms, culture, and different sectors might have different definitions and applications of these concepts. The actual exposure in each of the different studies is therefore difficult to compare. Until more standardized methods of measuring the physiological stressors of long work hours and shift work are commonly used, the accuracy in reporting exposure data in this field will remain low.

Many of the studies regarding work time and shift work are cross-sectional and use self-reported accidents as the outcome measure. This is a weakness. However, this is not only the case for accidents, but also many other outcomes. As such, accidents are more available to objective reporting than many other outcomes such as sleepiness, fatigue, musculoskeletal symptoms etc.

Our selection process included papers published in English only. It may be argued that this in itself may be a bias. However, the inclusion of any other language would produce a larger bias, given the limited knowledge of languages represented in our study group. Therefore, studies in - for instance - Scandinavian languages, (which would be easy for the group to read) were not included in our study.

The general findings of this study as shown in table 2 and figure 2 , are based on 14 studies that were scored as being of a high quality (total score 2 or 3 on a scale from 0-3) out of 43 studies that resulted from our selection process.

Although the scoring system we used has its weaknesses since it is based on an evaluation of a select group of parameters by different researchers, the set of papers we described above should be a relatively balanced set representing current knowledge in this field. The current study is different from most other review studies regarding the systematic approach. A systematic review will in practice provide only a sample of the studies that have been performed in this research field. However, this would probably be the case for nearly all reviews. Covering all studies ever performed with relevance to this field would not be possible, so there will always be some form of selection. The selection method most commonly used for review studies is a narrative approach using all available and known literature to the researchers performing the review, including papers that are believed to be of good quality regarding methodology and findings. The strength of such an approach is that many good studies are usually included. The weakness, however, is there would always be a researcher bias regarding which papers and findings are thought to be important or useful. The process leading up to this paper included discussions regarding papers that were known to us to be of good quality work in this field, including studies performed by well-known colleagues. These were still not included in this review as in gaining a larger sample, we would damage the balance of the studies included, thus maybe affecting the conclusions. We therefore chose to keep the study strictly as a systematic review; we believe this review contains a representative sample of current knowledge, which should mean that the results are not skewed in any one direction.

It is difficult to assume anything regarding possible publication bias, so this will, as in all review studies, be an unknown. However, many of the larger studies investigate many effects in the same cohort and the same study, probably decreasing any trend to not publish negative findings. Arguably, in addition to the fact that negative findings may be less prone to publication, they may also be less prone to interest from the scientific community. Maybe a systematic review such as this might reduce the effects of researcher bias. Still, the findings that are summarized herein are probably not generalizable to all work situations or occupations, since there are so many factors that influence safety. With the above in mind, the findings of our study indicate that both shift work and long work hours present a substantial and well-documented detrimental effect on safety. All the studies that are included in this review have one or more significant findings in this respect. The magnitude of this effect varies according to the different exposure variables, as seen in figure 2. Looking at the graphical representation of the different studies, the trends are quite coherent although the increases in accident rates are mostly from $50 \%$ to $100 \%$. In epidemiological terms, these may be seen as rather small differences. The use of such data is therefore only of importance if the accident incidence is high or if accidents have large effects.

It is also important to note that the type of accident in these different studies varies. The outcome measure is therefore variable, but in many studies easy to count and define, as workplace accidents often are well registered due to liability issues.

The issue of confounding is always a difficult one in that a number of different factors may contribute to any outcome. Regarding accidents, there are of course multiple person- and situation-specific factors that may 
Table 2. Main characteristics and results of the 14 selected studies of shift work and safety risk. [NA=not available]

\begin{tabular}{|c|c|c|c|c|c|c|c|}
\hline $\begin{array}{l}\text { Study, year; } \\
\text { country }\end{array}$ & $\begin{array}{l}\text { Study design, popula- } \\
\text { tion, period and num- } \\
\text { ber of participants } \\
\text { (participation rate) }\end{array}$ & $\begin{array}{l}\text { Source of } \\
\text { exposure } \\
\text { information }\end{array}$ & $\begin{array}{l}\text { Source of } \\
\text { outcome } \\
\text { information }\end{array}$ & $\begin{array}{l}\text { Exposure versus } \\
\text { comparison }\end{array}$ & Measure of risk & $\begin{array}{l}\text { Point estimate } \\
\text { and P-value } \\
\text { or } 95 \% \text { confi- } \\
\text { dence interval }\end{array}$ & $\begin{array}{l}\text { Covariates } \\
\text { controlled for }\end{array}$ \\
\hline $\begin{array}{l}\text { Smith \& } \\
\text { Colligan (7), } \\
\text { 1982; USA }\end{array}$ & $\begin{array}{l}\text { Cross-sectional study } \\
\text { of } 885 \text { food-process- } \\
\text { ing workers }(60 \%)\end{array}$ & $\begin{array}{l}\text { Self-reported by } \\
\text { questionnaire }\end{array}$ & $\begin{array}{l}\text { Self-reported } \\
\text { by question- } \\
\text { naire, em- } \\
\text { ployee records } \\
\text { on health, } \\
\text { safety and sick } \\
\text { absence }\end{array}$ & $\begin{array}{l}\text { Afternoon-, night- } \\
\text { and rotating shifts } \\
\text { versus day work; } \\
\text { rotating shifts } \\
\text { versus other } \\
\text { shifts }\end{array}$ & $\begin{array}{l}\text { Difference in inju- } \\
\text { ry rate (Cochran- } \\
\text { Mantel-Haenzel } \\
\text { statistics) }\end{array}$ & NA & NA \\
\hline $\begin{array}{l}\text { Gold et al (8), } \\
\text { 1992; USA }\end{array}$ & $\begin{array}{l}\text { Cross-sectional study } \\
\text { of female nurses (593 } \\
\text { registered and } 42 \\
\text { licensed practi- } \\
\text { cal nurses in a } \\
\text { Massachusetts } \\
\text { hospital) } 1986(72 \%)\end{array}$ & $\begin{array}{l}\text { Self-reported by } \\
\text { questionnaire }\end{array}$ & $\begin{array}{l}\text { Self- } \\
\text { reported by } \\
\text { questionnaire }\end{array}$ & $\begin{array}{l}\text { Rotating shift } \\
\text { work versus day/ } \\
\text { evening work; } \\
\text { night work versus } \\
\text { day/evening work }\end{array}$ & Odds ratio & $\begin{array}{l}\text { Rotating } \\
\text { shift: } 1.97 \\
(1.07-3.63) \\
\text { Night } \\
\text { work: } 1.88 \\
(0.88-4.02)\end{array}$ & $\begin{array}{l}\text { Age }<35 \text {, } \\
\text { working at the } \\
\text { hospital } \\
<1 \text { year, use of } \\
\text { alcohol to get } \\
\text { to sleep }\end{array}$ \\
\hline $\begin{array}{l}\text { Hänecke et } \\
\text { al (9), 1998; } \\
\text { Germany }\end{array}$ & $\begin{array}{l}\text { Ecological study of } \\
\text { the German working } \\
\text { population, } 1.2 \text { mil- } \\
\text { lion registered acci- } \\
\text { dents in } 1994\end{array}$ & $\begin{array}{l}\text { Two independent } \\
\text { surveys on work- } \\
\text { hours in Germany } \\
\text { (1992 and 1995) } \\
\text { as basis for } \\
\text { exposure models }\end{array}$ & $\begin{array}{l}\text { The } \\
\text { Confederation } \\
\text { of Worker's } \\
\text { Compensation } \\
\text { Board }\end{array}$ & $\begin{array}{l}\text { Hour at work } \\
\text { (duration), start- } \\
\text { ing time of work }\end{array}$ & $\begin{array}{l}\text { Relative accident } \\
\text { risk: ratio of ac- } \\
\text { cident frequen- } \\
\text { cies to calculated } \\
\text { exposure data } \\
\text { of working } \\
\text { population }\end{array}$ & NA & NA \\
\hline $\begin{array}{l}\text { Gander et al } \\
(10), 2000 ; \\
\text { New Zealand }\end{array}$ & $\begin{array}{l}\text { Cross-sectional study } \\
\text { of } 301 \text { New Zealand } \\
\text { full-time anesthetists } \\
\text { (183 specialists, } 44 \\
\text { registered trainees, } \\
\text { and } 9 \text { others }(70 \%)\end{array}$ & $\begin{array}{l}\text { Self-reported by } \\
\text { questionnaire }\end{array}$ & $\begin{array}{l}\text { Self- } \\
\text { reported by } \\
\text { questionnaire }\end{array}$ & $\begin{array}{l}\text { Reported work } \\
\text { hours (i) among } \\
\text { trainees versus } \\
\text { specialists (ii) } \\
\text { versus self- } \\
\text { defined work hour } \\
\text { limits for safety }\end{array}$ & $\begin{array}{l}\text { Risk ratios of } \\
\text { fatigue-related } \\
\text { errors }\end{array}$ & $\begin{array}{l}1.48 \text { (1.21- } \\
1.80 \text { ) (special- } \\
\text { ists exceeding } \\
\text { safe maximum } \\
\text { limit for work } \\
\text { hours in a } \\
\text { 7-day period) }\end{array}$ & $\begin{array}{l}\text { Years of } \\
\text { practice, } \\
\text { having } \\
\text { exceeded } \\
\text { self-defined } \\
\text { limits for work } \\
\text { duration }\end{array}$ \\
\hline $\begin{array}{l}\text { Landrigan et } \\
\text { al (11), 2004; } \\
\text { USA }\end{array}$ & $\begin{array}{l}\text { Prospective, random- } \\
\text { ized, crossover study } \\
\text { of interns in intensive } \\
\text { care units } 22023 \\
\text { patient-days, } 634 \\
\text { admissions }\end{array}$ & $\begin{array}{l}\text { Traditional work } \\
\text { schedule: } 77-81 \\
\text { hours/week; } \\
\text { intervention } \\
\text { schedule: } 63 \\
\text { hours/week }\end{array}$ & $\begin{array}{l}\text { Identification } \\
\text { of incidents } \\
\text { by multidisci- } \\
\text { plinary team. } \\
\text { Incidence- } \\
\text { rating by two } \\
\text { Independent } \\
\text { physicians }\end{array}$ & $\begin{array}{l}\text { Schedule with ex- } \\
\text { tended workshifts } \\
\text { versus interven- } \\
\text { tion schedule } \\
\text { without extended } \\
\text { work shifts }\end{array}$ & $\begin{array}{l}\text { Rates of serious } \\
\text { medical errors } \\
\text { by interns per } \\
1000 \text { patient- } \\
\text { days in traditional } \\
\text { and intervention } \\
\text { schedules }\end{array}$ & $\begin{array}{l}\text { Traditional } \\
\text { sched- } \\
\text { ule: } 193.2 ; \\
\text { Intervention } \\
\text { sched- } \\
\text { ule: } 158.4 \\
(P<0.001)\end{array}$ & NA \\
\hline $\begin{array}{l}\text { Rogers et al } \\
(12), 2004 ; \\
\text { USA }\end{array}$ & $\begin{array}{l}\text { Cross-sectional study } \\
\text { of } 393 \text { full time } \\
\text { hospital staff nurses, } \\
\text { members of the } \\
\text { American Nurses } \\
\text { Association } 2002 \\
(40 \%)\end{array}$ & Logbook & Logbook & $\begin{array}{l}\text { Duration of dif- } \\
\text { ferent shift sched- } \\
\text { ules including } \\
\text { overtime versus } \\
\text { schedules without } \\
\text { overtime }\end{array}$ & $\begin{array}{l}\text { Odds ratios of } \\
\text { errors when work } \\
\text { duration } 8.5-12.5 \\
\text { hours versus } \\
<8.5 \text { hand } \geq 12.5 \\
\text { hours versus } \\
<8.5 \text { hours }\end{array}$ & $\begin{array}{l}1.85(P=0.06) \\
3.29(P=0.001)\end{array}$ & $\begin{array}{l}\text { Age, hospital } \\
\text { size, type of } \\
\text { hospital unit }\end{array}$ \\
\hline $\begin{array}{l}\text { Garbarino et al } \\
(13), 2004 \text {; Italy }\end{array}$ & $\begin{array}{l}\text { Retrospective cohort } \\
\text { study of } 1195 \text { car } \\
\text { accidents by police } \\
\text { drivers during 1993- } \\
\text { 1997. Prospective } \\
\text { study of } 84 \text { accidents } \\
\text { in } 2003(93 \%)\end{array}$ & $\begin{array}{l}\text { Administrative } \\
\text { registers. Sleep } \\
\text { info from } 1195 \\
\text { phone interviews } \\
\text { in } 1999 \text { and } 84 \text { in } \\
2003\end{array}$ & $\begin{array}{l}\text { Italian state } \\
\text { traffic police }\end{array}$ & $\begin{array}{l}\text { Accidents among } \\
\text { drivers adopting } \\
\text { prophylactic naps } \\
\text { versus drivers } \\
\text { who did not nap }\end{array}$ & $\begin{array}{l}\text { Percent decrease } \\
\text { of accidents when } \\
\text { napping; hazard } \\
\text { ratio }\end{array}$ & $\begin{array}{l}\text { Retrospective } \\
\text { study: } 38 \% \text { de- } \\
\text { crease of risk, } \\
(P<0.001) ; \\
\text { prospective } \\
\text { study: } 48 \% \\
\text { decrease of } \\
\text { risk, }(P<0.05)\end{array}$ & $\begin{array}{l}\text { Timing and } \\
\text { duration of } \\
\text { naps }\end{array}$ \\
\hline $\begin{array}{l}\text { Barger et al } \\
(14), 2005 ; \\
\text { USA }\end{array}$ & $\begin{array}{l}\text { Prospective cohort } \\
\text { study of interns in } \\
\text { their first post- } \\
\text { graduate year }(2002- \\
2003) . N=2737(80 \%)\end{array}$ & $\begin{array}{l}\text { Self-reported by } \\
\text { questionnaire }\end{array}$ & $\begin{array}{l}\text { Self-reported } \\
\text { by question- } \\
\text { naire, docu- } \\
\text { mented by } \\
\text { police report, } \\
\text { insurance } \\
\text { claim, } \\
\text { photograph, } \\
\text { medical record } \\
\text { etc.) }\end{array}$ & $\begin{array}{l}\text { Extended versus } \\
\text { non-extended } \\
\text { work shifts. }\end{array}$ & $\begin{array}{l}\text { Odds ratio of (i) } \\
\text { motor vehicle } \\
\text { crashes; } \\
\text { (ii) falling asleep, } \\
\text { by number of } \\
\text { extended work } \\
\text { shifts }\end{array}$ & $\begin{array}{l}\text { (i) } 2.3(1.6- \\
3.3) \text {, after an } \\
\text { extended work } \\
\text { shift } \\
\text { (ii) } 2.39(2.31- \\
2.46) \text { when } \geq 5 \\
\text { extended work } \\
\text { shifts/month }\end{array}$ & NA \\
\hline $\begin{array}{l}\text { Dong (15), } \\
\text { 2005; USA }\end{array}$ & $\begin{array}{l}\text { Cohort study of } \\
12686 \text { working adults } \\
\text { 1992-1998. }\end{array}$ & $\begin{array}{l}\text { The national lon- } \\
\text { gitudinal survey } \\
\text { of youth, } 1979 \\
\text { cohort. Annual } \\
\text { interviews 1979- } \\
\text { 1994, biannual } \\
\text { from 1996 }\end{array}$ & $\begin{array}{l}\text { The national } \\
\text { longitudi- } \\
\text { nal survey of } \\
\text { youth, } 1979 \\
\text { cohort. Annual } \\
\text { interviews } \\
1979-1994, \\
\text { biannual from } \\
1996\end{array}$ & $\begin{array}{l}\text { Various work } \\
\text { schedules and } \\
\text { work hours in } \\
\text { production occu- } \\
\text { pations versus } 40 \\
\text { hours a week, or } \\
7 \text { - } 8 \text { hours a day }\end{array}$ & $\begin{array}{l}\text { Odds ratio for se- } \\
\text { vere work-related } \\
\text { injuries }\end{array}$ & $\begin{array}{l}1.98(1.88- \\
2.05) \text { for } \\
\text { weekly hours } \\
>501.21 \\
(1.20-1.21) \\
\text { For shift work }\end{array}$ & $\begin{array}{l}\text { Various, } \\
\text { unspecified }\end{array}$ \\
\hline
\end{tabular}


Table 2. Continued

\begin{tabular}{|c|c|c|c|c|c|c|c|}
\hline $\begin{array}{l}\text { Study, year; } \\
\text { country }\end{array}$ & $\begin{array}{l}\text { Study design, popula- } \\
\text { tion, period and num- } \\
\text { ber of participants } \\
\text { (participation rate) }\end{array}$ & $\begin{array}{l}\text { Source of } \\
\text { exposure } \\
\text { information }\end{array}$ & $\begin{array}{l}\text { Source of } \\
\text { outcome } \\
\text { information }\end{array}$ & $\begin{array}{l}\text { Exposure versus } \\
\text { comparison }\end{array}$ & Measure of risk & $\begin{array}{l}\text { Point estimate } \\
\text { and P-value } \\
\text { or } 95 \% \text { confi- } \\
\text { dence interval }\end{array}$ & $\begin{array}{l}\text { Covariates } \\
\text { controlled for }\end{array}$ \\
\hline $\begin{array}{l}\text { Dembe (16), } \\
\text { 2005; USA }\end{array}$ & $\begin{array}{l}\text { Cohort study of } \\
10793 \text { working } \\
\text { adults } 1987-2000\end{array}$ & $\begin{array}{l}\text { The national lon- } \\
\text { gitudinal survey of } \\
\text { youth, based on } \\
\text { annual/biannual } \\
\text { interviews }\end{array}$ & $\begin{array}{l}\text { The national } \\
\text { longitudi- } \\
\text { nal survey } \\
\text { of youth, } \\
\text { based on an- } \\
\text { nual/biannual } \\
\text { interviews }\end{array}$ & $\begin{array}{l}\text { Overtime and } \\
\text { extended work } \\
\text { schedules versus } \\
\text { no overtime }\end{array}$ & $\begin{array}{l}\text { Injury hazard } \\
\text { ratio }\end{array}$ & $\begin{array}{l}\text { Jobs with } \\
\text { overtime work: } \\
1.61(1.43- \\
1.79) ; \text { work } \\
>12 \text { hours / } \\
\text { day } 1.37 \\
(1.16-1.59)\end{array}$ & $\begin{array}{l}\text { Age, gender, } \\
\text { occupation, } \\
\text { industry, } \\
\text { region }\end{array}$ \\
\hline $\begin{array}{l}\text { Dembe (17) } \\
\text { 2006; USA }\end{array}$ & $\begin{array}{l}\text { Cohort study of } \\
10793 \text { working } \\
\text { adults } 1987-2000\end{array}$ & $\begin{array}{l}\text { The national lon- } \\
\text { gitudinal survey of } \\
\text { youth, based on } \\
\text { annual/biannual } \\
\text { interviews }\end{array}$ & $\begin{array}{l}\text { The national } \\
\text { longitudi- } \\
\text { nal survey } \\
\text { of youth, } \\
\text { based on an- } \\
\text { nual/biannual } \\
\text { interviews }\end{array}$ & $\begin{array}{l}\text { Night- and } \\
\text { evening shifts } \\
\text { versus day shifts }\end{array}$ & $\begin{array}{l}\text { Injury hazard } \\
\text { ratio }\end{array}$ & $\begin{array}{l}\text { Evening } \\
\text { shifts: } 1.43 \\
(1.26-1.62) ; \\
\text { rotating shifts: } \\
1.36 \text { (1.17- } \\
1.58) ; \text { Night } \\
\text { shifts: } 1.30 \\
(1.12-1.52)\end{array}$ & $\begin{array}{l}\text { Age, gender, } \\
\text { occupation, } \\
\text { industry, } \\
\text { region }\end{array}$ \\
\hline $\begin{array}{l}\text { Hanowski et al } \\
(18), 2007 ; \text { NA }\end{array}$ & $\begin{array}{l}\text { Cross-sectional study } \\
\text { of } 73 \text { commercial- } \\
\text { vehicle drivers, from } \\
3 \text { licensed trucking } \\
\text { companies. }\end{array}$ & $\begin{array}{l}\text { Video-cameras, } \\
\text { questionnaires, } \\
\text { actigraphs }\end{array}$ & $\begin{array}{l}\text { Video cameras, } \\
\text { software pro- } \\
\text { gram (search- } \\
\text { ing data-files } \\
\text { for spikes in } \\
\text { sensors) }\end{array}$ & $\begin{array}{l}\text { Sleep hours be- } \\
\text { fore incident ver- } \\
\text { sus mean overall } \\
\text { sleep quantity }\end{array}$ & $\begin{array}{l}P(T<t) \\
\text { (two-tailed) }\end{array}$ & $\begin{array}{l}-4.5177 \\
(P=0.0001)\end{array}$ & NA \\
\hline $\begin{array}{l}\text { Fransen et al } \\
(19), 2006 ; \\
\text { New Zealand }\end{array}$ & $\begin{array}{l}\text { Cross sectional study } \\
\text { of } 15687 \text { blood do- } \\
\text { nors }(70 \%)\end{array}$ & $\begin{array}{l}\text { Self-reported by } \\
\text { questionnaire }\end{array}$ & $\begin{array}{l}\text { Self- } \\
\text { reported by } \\
\text { questionnaire }\end{array}$ & $\begin{array}{l}\text { Rotating shifts } \\
\text { with nights } \\
\text { vs daytime } \\
\text { Permanent night } \\
\text { shifts versus day- } \\
\text { time }>40 \text { hours } \\
\text { versus } \leq 40 \mathrm{~h}\end{array}$ & Relative risk & $\begin{array}{l}1.75(1.17- \\
2.61) 1.38 \\
(0.93- \\
2.00) 1.32 \\
(1.12-1.55)\end{array}$ & $\begin{array}{l}\text { Gender, edu- } \\
\text { cation, smok- } \\
\text { ing, daytime } \\
\text { sleep vari- } \\
\text { ables, head- } \\
\text { aches, body } \\
\text { mass index, } \\
\text { occupation }\end{array}$ \\
\hline $\begin{array}{l}\text { Vegso et al (20) } \\
2007 \text {; USA }\end{array}$ & $\begin{array}{l}\text { Case-crossover study } \\
\text { of } 1955 \text { manufac- } \\
\text { turing workers, } \\
\text { 1999-2002 }\end{array}$ & $\begin{array}{l}\text { Five metal } \\
\text { production plants }\end{array}$ & $\begin{array}{l}\text { Companies' in- } \\
\text { cident manage- } \\
\text { ment system }\end{array}$ & $\begin{array}{l}\text { Hours worked } \\
\text { prior to injury } \\
\text { shift versus hours } \\
\text { worked prior to } \\
\text { non-injury shift }\end{array}$ & $\begin{array}{l}\text { Injury hazard } \\
\text { ratio }\end{array}$ & $\begin{array}{l}\text { Work time } \\
>64 \text { hours/ } \\
\text { week versus } \\
\leq 40 \text { hours/ } \\
\text { week } 1.88 \\
(1.16-3.05)\end{array}$ & NA \\
\hline
\end{tabular}

contribute to an unwanted outcome. Therefore, the fact that the trend is so clear for both long work hours and shift work in a review like this with many different studies strengthens our conclusions. However, epidemiological studies will always have their limitations, which will not necessarily be compensated for by the performance of a systematic review.

The general trends in this study are similar to that of most other reviews concerning shift work and safety, even though most reviews to date are not based on an explicitly systematic selection of studies. Examples of recent reviews that have similar findings are Folkard \& Tucker (5), Knauth (4), and Holley et al (21).

Naturally, in safety-critical activities, the issue of long work hours and shift work has been deemed important in the prevention of accidents. Knauth et al (4) concluded in a review of 105 studies on extended daily working hours that caution is advised when considering the introduction of work shifts, particularly where public safety is at stake. Many sectors have implemented strict scheduling rules and regulations. There are however, large differences in the degree of restriction of long work hours between sectors. Thus, the health sector is one area where much con- troversy has fueled many studies in the last decade (22). As Åkerstedt (23) pointed out already in 1995, there is ample evidence of impaired safety to work-hour-induced fatigue. He also pointed out that lack of information may be the cause of inadequate action by authorities or other organizations in this area. Given the rather obvious differences that remain between sectors on work shift regulations, it may seem that this may still be the case.

\section{Specific shift schedules}

Safety effects of different shift schedules have been specifically studied. Many factors contribute to accidents, and a broad view is important regarding preventive policies. However, there are some general findings that are of interest.

\section{Rotating shifts in general}

Several studies indicate that rotating shifts may carry a higher safety risk than regular night shifts $(7,19)$. This may be connected to a certain degree of shift synchronization with regular night shifts. Although synchroni- 


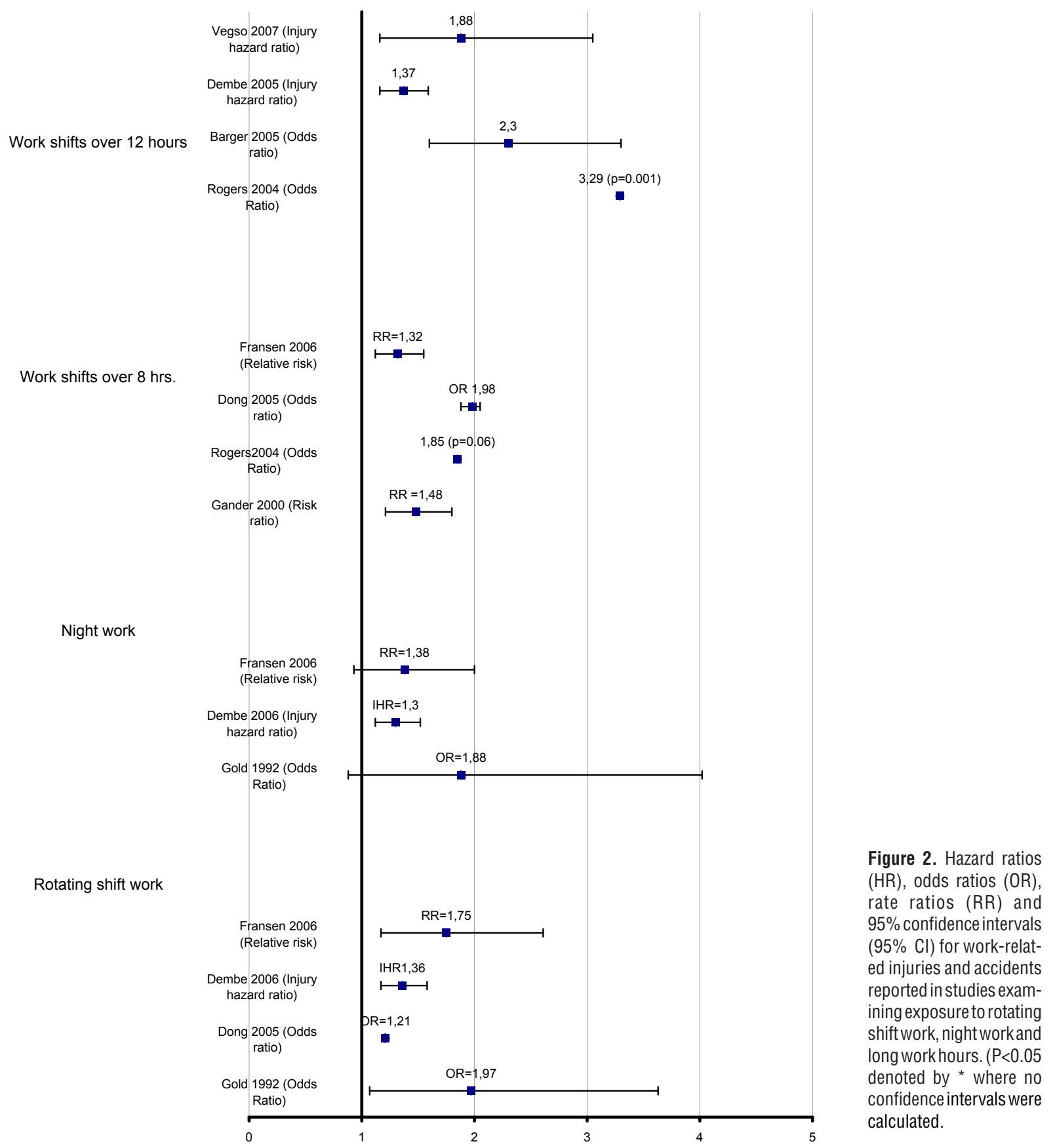

zation to an "unnatural" daily rhythm may have other health consequences, it may be seen as paradoxical that safety-wise it could be of preference to rotate shifts. This shows that preventive action is complicated and requires well-founded strategies.

\section{Age and gender}

Our systematic review did not reveal any conclusion regarding the effect of age or gender on accident risk. This is a difficult issue to examine. Young people are in general known to be more accident prone. One might assume that elderly people, arguably being more susceptible to sleep problems, may have greater difficulties in managing shift work over time. Even though it seems that there is no clear epidemiological evidence to support this, it might still be true. Maybe the older workforce doing shift work is the result of significant self-selection, ie, those keeping up working shifts being those who have few problems with it. This "healthy-worker effect" may of course also be the source of other underestimations in epidemiological studies of shift work. 


\section{Concluding remarks}

Our systematic review revealed the following main findings: (i) both long hours and shift and night work affect accident risk. This is of importance to all organizations and workers, but of particular importance to safety-critical activities; (ii) work periods of $>8$ hours carry an increased risk of accidents that cumulates, so that the increased risk of accidents at around 12 hours is twice the risk at 8 hours; (iii) shift work including nights carries a substantial increased risk of accidents, whereas "pure" night work may bring some protection against this effect due to resynchronization; (iv) the evaluated studies give no clear indications of any age or gender being specifically susceptible to or protected against the effects of work times scheduling on accident risk.

Since the epidemiological evidence of shift work and long work hours on safety is rather clear, future studies should focus more on mechanisms and improvement strategies. Standardization of exposure and outcome variables would also make it easier to compare results between different sectors.

\section{References}

1. Driscoll T, Takala J, Steenland K, Corvalan C, Fingerhut M. Review of estimates of the global burden of injury and illness due to occupational exposures. Am J Ind Med. 2005;48:491-502. doi:10.1002/ajim.20194.

2. Reason J. Understanding adverse events: human factors. Qual Health Care. 1995;4:80-89. doi:10.1136/qshc.4.2.80.

3. Åkerstedt T. Psychological and psychophysiological effects of shift work. Scand J Work Environ Health. 1990;16 Suppl $1: 67-73$.

4. Knauth P. Extended work periods. Industrial Health. 2007;45:125-136. doi:10.2486/indhealth.45.125.

5. Folkard S, Tucker P. Shift work, safety and productivity. Occup Med (Lond). 2003;53:95-101. doi:10.1093/occmed/kqg047.

6. Lie JA, Gulliksen E, Bast-Pettersen R, Skogstad M, Tynes T, Wagstaff A. Arbeidstid og helse - En systematisk litteraturstudie [Work schedules and health - A systematic literature review]. In: National institute of Occupational Health, ed. Oslo: STAMI, 2008. [Cited 2 February] Available from: http://www.stami.no/?nid=52315\&lcid=1044.

7. Smith MJ, Colligan MJ. Health and Safety Consequences of Shift Work in the Food-Processing Industry. Ergonomics. 1982;25:133-144. doi:10.1080/00140138208924933.

8. Gold DR, Rogacz S, Bock N, et al. Rotating shift work, sleep, and accidents related to sleepiness in hospital nurses. Am J Public Health. 1992;82:1011-1014. doi:10.2105/ AJPH.82.7.1011.

9. Hanecke K, Tiedemann S, Nachreiner F, Grzech-Sukalo H. Accident risk as a function of hour at work and time of day as determined from accident data and exposure models for the German working population. Scand J Work Environ Health. 1998;24 Suppl 3:43-48.

10. Gander PH, Merry A, Millar MM, Weller J. Hours of work and fatigue-related error: a survey of New Zealand anaesthetists. Anaesth Intensive Care. 2000;28:178-183.

11. Landrigan CP, Rothschild JM, Cronin JW, et al. Effect of reducing interns' work hours on serious medical errors in intensive care units. N Engl J Med. 2004;351:1838-1848. doi:10.1056/NEJMoa041406.

12. Rogers AE, Hwang WT, Scott LD, Aiken LH, Dinges DF. The working hours of hospital staff nurses and patient safety. Health Affairs. 2004;23:202-212. doi:10.1377/hlthaff.23.4.202.

13. Garbarino S, Mascialino B, Penco MA, et al. Professional shiftwork drivers who adopt prophylactic naps can reduce the risk of car accidents during night work. Sleep. 2004;27:1295-1302.

14. Barger LK, Cade BE, Ayas NT, et al. Extended work shifts and the risk of motor vehicle crashes among interns. N Engl J Med. 2005;352:125-134. doi:10.1056/NEJMoa041401.

15. Dong X. Long workhours, work scheduling and work-related injuries among construction workers in the United States. Scand J Work Environ Health. 2005;31:329-335.

16. Dembe AE, Erickson JB, Delbos RG, Banks SM. The impact of overtime and long work hours on occupational injuries and illnesses: new evidence from the United States. Occup Environ Med. 2005;62:588-597. doi:10.1136/oem.2004.016667.

17. Dembe AE, Erickson JB, Delbos RG, Banks SM. Nonstandard shift schedules and the risk of job-related injuries. Scand J Work Environ Health. 2006;32:232-240.

18. Hanowski RJ. The sleep of commercial vehicle drivers under the 2003 hours-of-service regulations. Accid Anal Prev. 2007;41:268-275. doi:10.1016/j.aap.2008.11.007.

19. Fransen M, Wilsmore B, Winstanley J, et al. Shift work and work injury in the New Zealand Blood Donors' Health Study. Occup Environ Med. 2006;63:352-358. doi:10.1136/ oem.2005.024398.

20. Vegso S, Cantley L, Slade M, et al. Extended work hours and risk of acute occupational injury: A case-crossover study of workers in manufacturing. American Journal of Industrial Medicine. 2007;50:597-603. doi:10.1002/ajim.20486.

21. Holley DC, Sundaram B, Wood DK. Shift work and aviation safety. Clin Occup Environ Med. 2003;3(2):231-262. doi:10.1016/S1526-0046(03)00073-6.

22. Lockley SW, Landrigan CP, Barger LK, Czeisler CA. When policy meets physiology: the challenge of reducing resident work hours. Clin Orthop Relat Res. 2006;449:116-127.

23. Åkerstedt T. Work hours, sleepiness and accidents: Introduction and summary. Journal of Sleep Research. 1995;Supplement $4(2): 1-3$.

Received for publication: 17 March 2010 